The Roof at the Bottom of the World 


\section{The Roof}

at the Bottom

of the World

Discovering the

Transantarctic

Mountains

Edmund Stump

Yale UNIVERSITY PRESS

NEW HAVEN AND LONDON 
Frontispiece: Atop the Tusk, a 600-foot horn of pure marble, a seeker contemplates the scene. In the distance Mount Fridtjof Nansen rises to an elevation of 13,350 feet above Liv Glacier, flowing from the right rear of the photo. Roald Amundsen's party found passage to the polar plateau on the far side of Fridtjof Nansen, becoming the first to reach the South Pole on December 16, 1911. Eighteen years later, Richard Byrd navigated the first flight to the pole, following a course up Liv Glacier.

Copyright $\odot 2011$ by Edmund Stump. All rights reserved. This book may not be reproduced, in whole or in part, including illustrations, in any form (beyond that copying permitted by Sections 107 and 108 of the U.S. Copyright Law and except by reviewers for the public press), without written permission from the publishers.

Yale University Press books may be purchased in quantity for educational, business, or promotional use. For information, please e-mail sales.press@yale.edu (U.S. office) or sales@yaleup.co.uk (U.K. office).

Designed by Nancy Ovedovitz. Set in Galliard Oldstyle and The Sans Semibold type by BW\&A Books, Inc. Printed in China.

\section{Library of Congress Cataloging-in-Publication Data}

Stump, Edmund.

The roof at the bottom of the world : discovering the Transantarctic Mountains / Edmund Stump.

p. $\mathrm{cm}$.

Includes bibliographical references and index.

ISBN 978-0-300-17197-6 (cloth : alk. paper) 1. Orogeny-Antarctica-Transantarctic Mountains. 2. Geology-Antarctica-Transantarctic Mountains. 3. Transantarctic Mountains (Antarctica) I. Title.

OE621.5.A6s77 2011

$551.43^{\prime 2} 209989-d c 22 \quad 2011006403$

A catalogue record for this book is available from the British Library.

This paper meets the requirements of ANSI/NISO z39.48-1992 (Permanence of Paper).

10987654321 
Publication of The Roof at the Bottom of the World has been made possible by the generous support of the following benefactors:

Scion Natural History Association

Daryl A. Russell

Bear Gulch Foundation

Harry Rubin, in memory of Morton J. Rubin, whose interest in Antarctica took him there many times, including fifteen months with the Russians at Mirny Station during the IGY

James W. Collinson

Thomas Henderson

Julia and Ralph Maccracken

Julie Smith-David and Scott David

John Splettstoesser

Marjory Spoerri

and

School of Earth and Space Exploration

College of Liberal Arts and Sciences

Arizona State University 
This book is dedicated to the memory of my parents, Sis and Warren,

for encouragement,

for discipline,

and this body that takes me the places I've been. 